\title{
High-power Yb- and Tm-doped double tungstate channel waveguide lasers
}

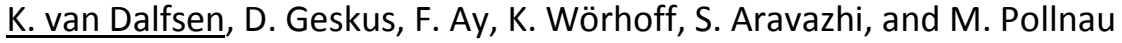 \\ Integrated Optical MicroSystems (IOMS) Group, MESA+ Institute for Nanotechnology, \\ University of Twente, 7500 AE Enschede, The Netherlands \\ phone: +31-53-489 4440, fax: +31-53-489 3996 \\ e-mail: k.vandalfsen@utwente.nl
}

The potassium double tungstates $\mathrm{KGd}\left(\mathrm{WO}_{4}\right)_{2}, \mathrm{KY}\left(\mathrm{WO}_{4}\right)_{2}$, and $\mathrm{KLu}\left(\mathrm{WO}_{4}\right)_{2}$ are excellent candidates for solid-state lasers [1] because of their high refractive index of $\sim 2.0-2.1$, the large transition cross-sections of rare-earth $\left(\mathrm{RE}^{3+}\right)$ ions doped into these hosts, and a reasonably large thermal conductivity of $\sim 3.3 \mathrm{~W} \mathrm{~m}^{-1} \mathrm{~K}^{-1}$. Exploiting these advantages, $\mathrm{Yb}$ - [2] and Tm-doped [3] $\mathrm{KY}\left(\mathrm{WO}_{4}\right)_{2}$ planar waveguide lasers were demonstrated. Co-doping of $\mathrm{KY}\left(\mathrm{WO}_{4}\right)_{2}: \mathrm{RE}^{3+}$ thin films with $\mathrm{Gd}^{3+}$ and $\mathrm{Lu}^{3+}$ ions provides lattice matching and enhanced refractive index contrast of up to $7.5 \times 10^{-3}$ with respect to the $\mathrm{KY}\left(\mathrm{WO}_{4}\right)_{2}$ substrate, thus thinner waveguides with better mode confinement [4], enabling highly efficient planar waveguide lasers [5] and facilitating microstructuring.

We grew $\mathrm{KY}_{1-\mathrm{x}-\mathrm{y}} \mathrm{Gd}_{\mathrm{x}} \mathrm{Lu}_{\mathrm{y}}\left(\mathrm{WO}_{4}\right)_{2}: \mathrm{RE}^{3+}$ layers with various compositions onto undoped $\mathrm{KY}\left(\mathrm{WO}_{4}\right)_{2}$ by liquid phase epitaxy. Replacing $\mathrm{Y}^{3+}$ in the layer completely by $\mathrm{Gd}^{3+}$ and $\mathrm{Lu}^{3+}$ ions results in layers with a refractiveindex contrast of $>2 \times 10^{-2}$. Channel waveguides were microstructured into the layers by $\mathrm{Ar}^{+}$beam etching [6]. The excellent pump and signal mode confinement in these channel waveguides, combined with the aforementioned attractive properties of the host material, resulted in highly efficient lasers.

In $\mathrm{KGd}_{0.49} \mathrm{Lu}_{0.485} \mathrm{Yb}_{0.025}\left(\mathrm{WO}_{4}\right)_{2}$ channel waveguides with $\sim 0.34 \mathrm{~dB} / \mathrm{cm}$ propagation loss at $1.0 \mu \mathrm{m}$, channel waveguide lasers with butt-coupled mirrors delivered $418 \mathrm{~mW}$ of output power at $1023 \mathrm{~nm}$ with a slope efficiency of $71 \%$ (Fig. 1). By pumping at $973 \mathrm{~nm}$ and lasing at $980 \mathrm{~nm}$, a record-low quantum defect of $0.7 \%$ was achieved [7]. 4- $\mu$ m-deep Bragg gratings were etched by focused ion beam (FIB) milling. An on-chip integrated laser cavity was formed by this distributed Bragg reflector and a FIB-polished waveguide end-facet (Fig. 2) and the first on-chip integrated double tungstate waveguide laser at $980 \mathrm{~nm}$ was demonstrated [8].

In $\mathrm{KY}_{0.4} \mathrm{Gd}_{0.295} \mathrm{Lu}_{0.29} \mathrm{Tm}_{0.015}\left(\mathrm{WO}_{4}\right)_{2}$ channel waveguides with $\sim 0.11 \mathrm{~dB} / \mathrm{cm}$ propagation loss at $1.9 \mu \mathrm{m}$, laser experiments with butt-coupled mirrors demonstrated an output power of $149 \mathrm{~mW}$ and slope efficiency of 31.5\% when pumping at $794 \mathrm{~nm}$ in TM polarization (Fig. 3). The lowest threshold was $7 \mathrm{~mW}$. The laser wavelength shifted from $1930 \mathrm{~nm}$ via $1906 \mathrm{~nm}$ to $1846 \mathrm{~nm}$ with increasing outcoupling degree [9].

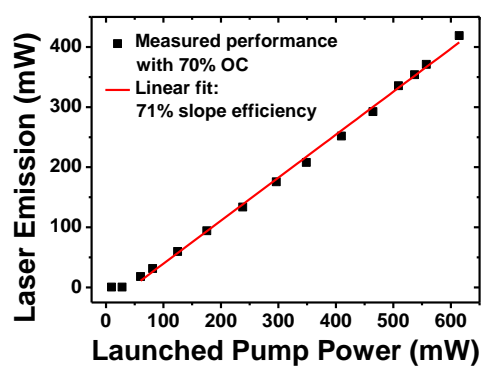

Fig. 1. Input-output curve of a $\mathrm{KGd}_{0.49} \mathrm{Lu}_{0.485} \mathrm{Yb}_{0.025}\left(\mathrm{WO}_{4}\right)_{2}$ channel waveguide laser at $1023 \mathrm{~nm}$, pumped at $981 \mathrm{~nm}$.

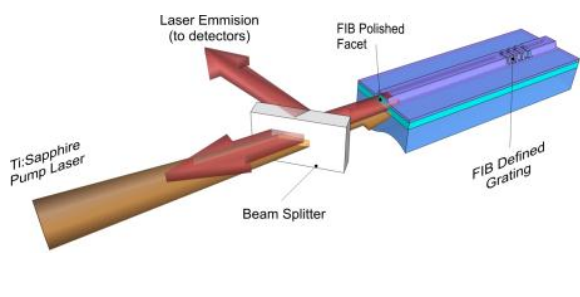

Fig. 2. An integrated laser with a distributed Bragg reflector cavity in a channel waveguide of $\mathrm{KGd}_{0.49} \mathrm{Lu}_{0.485} \mathrm{Yb}_{0.025}\left(\mathrm{WO}_{4}\right)_{2}$.

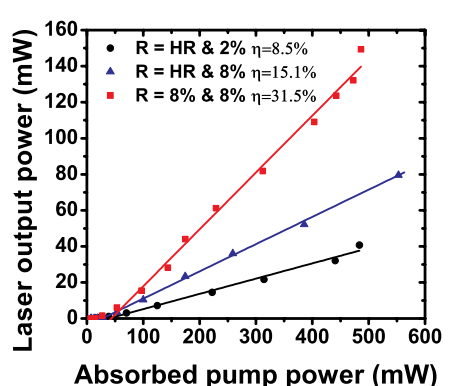

(a)

Fig. 3. Input-output curve of a $\mathrm{KY}_{0.4} \mathrm{Gd}_{0.295} \mathrm{Lu}_{0.29} \mathrm{Tm}_{0.015}\left(\mathrm{WO}_{4}\right)_{2}$ at 1.9 $\mu \mathrm{m}$, pumped at $794 \mathrm{~nm}$.

[1] M. Pollnau, Y. E. Romanyuk, F. Gardillou, C. N. Borca, U. Griebner, S. Rivier, and V. Petrov, IEEE J. Sel. Top. Quantum Electron. 13, 661-671 (2007).

[2] Y. E. Romanyuk, C. N. Borca, M. Pollnau, S. Rivier, V. Petrov, and U. Griebner, Opt. Lett. 31, 53-55 (2006).

[3] S. Rivier, X. Mateos, V. Petrov, U. Griebner, Y. E. Romanyuk, C. N. Borca, F. Gardillou, and M. Pollnau, Opt. Express 15, 5885-5892 (2007).

[4] F. Gardillou, Y. E. Romanyuk, C. N. Borca, R. P. Salathé, and M. Pollnau, Opt. Lett. 32, 488-490 (2007).

[5] D. Geskus, S. Aravazhi, E. Bernhardi, C. Grivas, S. Harkema, K. Hametner, D. Günther, K. Wörhoff, and M. Pollnau, Laser Phys. Lett. 6, 800-805 (2009).

[6] D. Geskus, S. Aravazhi, C. Grivas, K. Wörhoff, and M. Pollnau, Opt. Express 18, 8853-8858 (2010).

[7] D. Geskus, S. Aravazhi, K. Wörhoff, and M. Pollnau, Opt. Express 18, 26107-26112 (2010).

[8] F. Ay, I. Iñurrategui, D. Geskus, S. Aravazhi, and M. Pollnau, Laser Phys. Lett. 8, 423-430 (2011).

[9] K. van Dalfsen, S. Aravazhi, D. Geskus, K. Wörhoff, and M. Pollnau, Opt. Express 19, 5277-5282 (2011). 